\title{
SEEFESR Learning Model as an Approach to Improve Quality of Learning
}

\author{
Sri Sumarni ${ }^{1}$ \\ ${ }^{1}$ The Faculty of Teacher Training and Education Sebelas Maret University Indonesia \\ email: marnis_ri@yahoo.com
}

\begin{abstract}
SEEFESR (see, find, explain, share, and record) is a learning method which has the following steps: gathering information, finding answers in pairs, explain the answers to each other in pair, presenting the answers of each pairs before the class, and repeating the explanation by recording it in audio or video format. The objective of this research is to investigate whether the learning objective is achieved through SEEFESR. This research used the classroom action research. The results of the research are follows: the learning materials were entirely delivered; the students learned in the class to the phase of analyzing; there was a guarantee that students were learning; and the learning evaluation could be conducted objectively. Thus, the learning objective was achieved based on the learning achievement, and the learning process itself left a good impression on the students.
\end{abstract}

Keywords: learning model, SEEFESR (see, find, explain, share, and record)

\section{INTRODUCTION}

Learning method is a medium which determines the success of the learning objective. The learning objective itself is translated from the expected learning achievement. According to Bloom, there are six levels of learning achievement that the students must attain, namely: knowledge, comprehension, application, analysis, synthesis, and evaluation. Conklin, J. [6]. To meet satisfactory learning results, a proper learning method should be applied [10]. The application of a learning process can have a significant effect on the student's ability in educating themselves. Successful teachers are those who involve students in cognitive- and social-loaded assignments and educate them to do the assignments productively. For example, when the teachers lecture clearly and skilfully, the students who are subjected should remain learning from it. Successful educators will always teach their students on how to absorb and master the information coming from explanation. Meanwhile, effective learners should be able to illustrate information, ideas, and wisdom from their teachers, and also be able to use sources of learning in an effective way. Therefore, the main function of teaching is to produce reliable learners.

Based on the observation on Engineering Mechanics learning in Academic Year 2015/2016, the skills of student in absorbing and mastering the information were still low, the students not fully learned during the time allotted for discourse, and the teachers experienced difficulties in evaluating learning process of big classes, which consisted of 30-40 students. From the evaluation result of learning process using classical model, which was based on the result of assignment, quizzes, and tests, it 
was found that $89.19 \%$ passed the course. $18.92 \%$ of them got A, $27.13 \%$ got B, $40.54 \%$ got $\mathrm{C}$, and $10.8 \%$ got $\mathrm{D}$. The result did not reflect the learning completion.

Therefore, this research will apply an active learning method, which gives an opportunity to students to learn so that the students are expected to complete the learning through the application of SEEFESR method (see, find, explain, share, record). It is a cooperative-type method of learning, which is conducted in the following phases. First, the teacher explains the main course in classical way, and then divides the class into several learning groups consisting of 6-8 students each. After that, the teacher shares a different course material to each group, inviting them to discuss it in pairs within the respective group. If the pair fails to understand the material, they are permitted to ask other pairs within their group. In this way, the teacher monitors the development of discussion by acting as facilitator. The result of discussion in each group then is presented before the class, and recorded in a learning video. The recording is done by the pair in this way: one student explains the material, in writing or orally, and the other listens and recording it in video by phone camera. They do the recording alternately. Finally, the videos recorded were shared in the class so that the full material could be accessed and learned by all students. The syntaxes of SEEFESR method are gathering information, finding answers in pairs, explaining it to each other, presenting the answers from each group before the class, and recording the presentation of each group. The update offered by this research is the development of think-pair-share method (TPS) by adding the video recording process to the phase of understanding. It was done to deepen the process of learning.

Frank Lyman [15] claims that the think-pair-share (TPS) method needs waiting and thinking time in interactive element of cooperative learning, which is a factor in raising the students' response to questions. The benefits of the TPS are as follows: allowing students to work alone and work with others, optimizing the participation of students, and giving students the opportunity to show their participation to others. The skills needed in this information are information sharing, asking questions, summarizing ideas of others, and paraphrasing. The TPS itself is conducted in the following steps: (1) forming a learning group consisting of 4 students, (2) giving assignments to each group, (3) allowing each member of group to work on the assignment by himself/herself firstly, (4) encouraging the groups to form pairs within it and telling the pairs to discuss the individual result of work, and (5) telling the pairs in the groups to meet again with their group members to share their discussion results.

This research was inspired by the TPS method, following many researches which also applied the method, and which were successful in improving the learning process, including word lists (e.g. Fitzgerald, D. [7]; Lyman, F., \& Davidson, N. E. I. L. [13]; Kaddoura, M. [11]; Sugiarto, D., \& Sumarsono, P. [21]; McTighe, J., \& Lyman, F. T. [15]; Murthy, S., Warriem, J. M., \& Iyer, S. [16]; Hassumani, D., Cancellieri, S., Boudakov, I., Upadhya, S., \& Sobering, A. K. [8]; , O.S., at all 2013; Husna, at all, [9]; Surayya, at all, [24];Sumarni. S, [23]; Widiyaningsih. A [25]; Permadi Marhaeni, at al, [17]; Bamiro [4]; Rudiyanto, O. S., \& Sigit, D. [17]). 


\section{METHOD}

This research used the classroom action research method. Its objective is to increase our understanding of classroom learning and teaching [1]. For example, you may want to explore the strategies that young learners rely on in order to make sense of the stories that they hear, or you want to find out more about the way teachers' questions scaffold classroom interaction while talking about a story. Purposive sampling technique was used to determine its samples. The samples were the students of the Construction Engineering Education Department, the Faculty of Teacher Training and Education, Sebelas Maret University, the class of 2017, who took the course of Engineering Mechanics in class A. The data were then collected by using direct observation, written response, and documentations. Schunk D.H [20], claims that direct observation is a way to assess whether students actually learn during the lecture by observing the behavior of the students, while written responses include results of tests, quizzes, homework assignments, papers and projects. To determine the data validity, data triangulation was used. The data were analyzed by using the qualitative data analysis.

\section{SUBJECT}

The subjects of the research were 33 students who took the course of Engineering Mechanics 4 in class A in Academic Year 2017.

The data of the research were obtained from structured observation result by using observation guidelines, achievement test to investigate the learning achievement and documentations in the form of plans of learning implementation, photos, and videos.

\section{PROCEDURE}

The research was conducted by following these procedures, namely: learning process planning, learning process implementation, and evaluation.

The planning phase was conducted by preparing the lesson plans of each meeting for half semester. The learning objective stated was that the students are expected to be able to analyze structures with the application of moment-area theorem on statically indeterminate construction. The learning materials consisted of : (1) application of moment-area theorem to statically indeterminate constructions, which covers three-span beams, clasp-joint span beams, clasp-clasp span beams, and (2) Three-cycle moment theory (Clapeyron). The materials were delivered for 8 meetings with learning and test session.

The implementation phase was conducted by conducting lectures on Engineering Mechanics 4 by using SEEFESR method in accordance with preparing the lesson plans, with the learning duration of 2 hours of learning or 100 minutes. It was conducted in the steps as follows. First, the teacher delivered introduction to material coverage for 15 minutes, then the students were asked to learn in groups. The teacher then divided the class into 4 learning groups and each of them consisted of 8 students. After that, each group was given questions to be answered. The students were firstly asked to work their assignments individually, and then they were asked to pair with one person within their group members. After that, the pairs were asked 
to discuss the solutions of the questions. After having agreed to the answers, then the pairs came back to their respective groups, and shared the answers and made conclusion of group task result. Next, one of the groups presented their result before the class to uniform perception to the answers, and then it was discussed with the teacher. The next step, the students explained the solutions to their respective pairs while being recorded in audio or video format. The recording was done to deepen the ability of understanding the material. During the course of learning, the teacher functioned as a facilitator who always monitored and facilitated the learning process.

The phase of evaluation was conducted by giving assignments to the students. The students worked on the assignments individually to measure their cognitive ability.

\section{RESULT AND DISCUSSION}

\section{RESULTS}

In the first meeting, the teacher delivered the material of application of momentarea theorem in statically indeterminate beam, which is three-span beams, for 15 minutes, then it was continued with independent learning for 70 minutes, which consisted of dividing the class into 4 groups and each of which consisted of 8 students, and giving questions to each group. The process of doing the assignments was initiated by working on it individually, or reading the concept for 10 minutes, and then it was continued with pair discussion for 25 minutes until they agreed to the solution, and after that it was continued with discussion within groups to decide the group's solution for 15 minutes. Next, one of the groups presented their result before the class to uniform perception to the answers, and then it was discussed with the teacher. The next step, the students explained the solutions to their respective pairs while being recorded in audio or video format. The recording was done to deepen the ability of understanding the material. During the course of learning, the teacher functioned as a facilitator who always monitored and facilitated the learning process. The learning process by using SEEFESR method is shown in Figures 1-4.

The learning process in the second to the sixth meeting had the same sequence as above, with the difference in the materials delivered. The materials for the second to the sixth meeting were: clasp-joint span beams, clasp-clasp span beams, three-cycle moment theory (Clapeyron) on three-span beams, three-cycle moment theory (Clapeyron) on clasp-joint span beams, and three-cycle moment theory (Clapeyron) on clasp-clasp span beams. Testing phase was conducted on the seventh and eighth meetings.

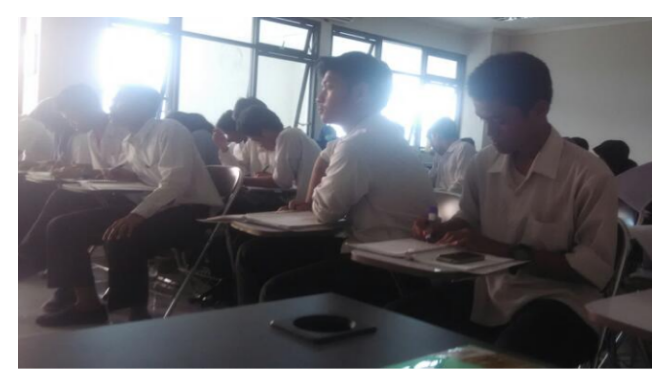

Figure 1. See Phase 


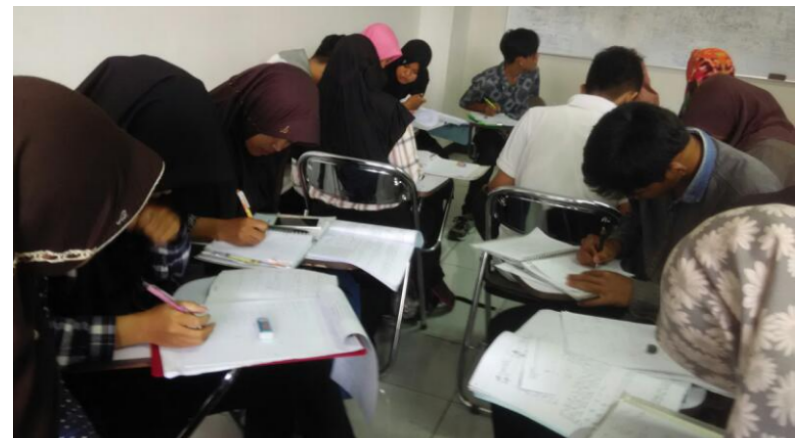

Figure 2. Find Phase

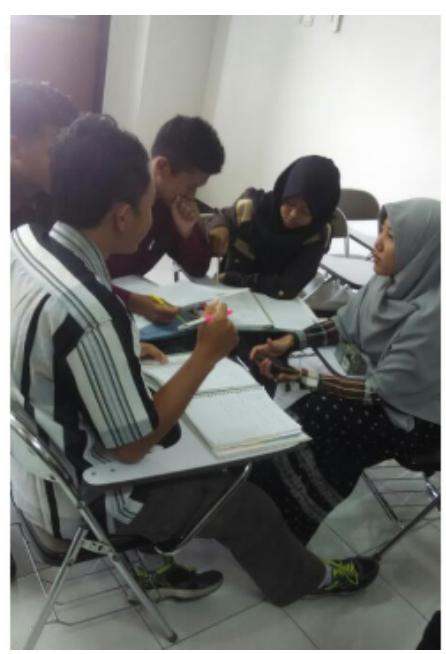

Figure 3. Explain Phase

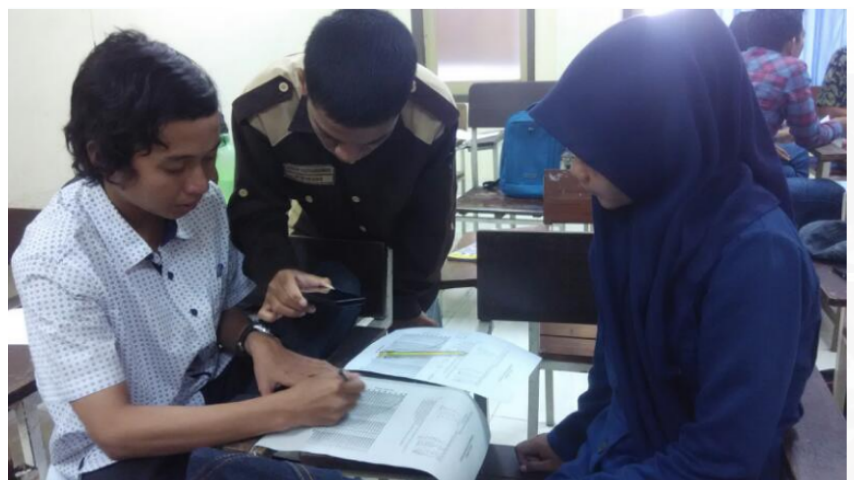

Figure 4. Explain and Record Phases

The learning result consisted of scores from cognitive, psychomotor, and affective domains, which were determined by group assignment results, discussion process, video records, and test results. The scoring of assignments, test, and video recording was based on the numerical scale of 1 to 100 , while the discussion score was obtained through scoring participation, attitude, and skills. The total score of learning result is shown in Table 1. 
TABLE 1. FINAL SCORE OF LEARNING RESULT

\begin{tabular}{ccc}
\hline Score & Number of students & Percentage (\%) \\
\hline $80-100$ & 4 & 12.12 \\
$70-79$ & 28 & 84.8 \\
$60-69$ & 1 & 3.03 \\
$<59$ & 0 & 0 \\
\hline
\end{tabular}

\section{DISCUSSION}

In learning process by using SEEFESR method, in which the plans of learning implementation had been made before, the learning materials could be delivered in accordance with the plans.

The achievement of learning objectives was based on Bloom's theory by using SEEFESR method. When the teacher delivered the material, the students learned to understand the theory and concept of application of moment-area theorem to statically indeterminate beams, which is three-span beam. When the students worked on the assignment individually, it was also called as the phase of understanding. Then, the students discussed the problems with their respective pairs and continued with group discussion and intergroup discussion respectively. At the time of discussion, the students were expected to have competences of information sharing, asking questions, summarizing ideas, and concluding the solutions to the problem. The process itself was based on Bloom's theory to create application and analysis ability. The next process, in which the students explained the solutions to their respective pairs while being recorded in audio or video format, was conducted to deepen the understanding of the material, and to measure the ability of explaining the material, since the learning process was conducted over and over. According to Brown and Saks [5] the learning effort of the students has two dimensions, namely: the amount of time spent by student in a learning process and the intensity and involvement in learning. John b carroll (1963) stated that the essential variables in learning are: (1) aptitude, which is the ideal amount of time which the students have to meet the learning objectives, (2) perseverance, which is the amount of time actually spent by students to learn, and (3) opportunity to learn, which is the amount of time allotted to learning. Two other components which have significant influence are the ability to understand and the quality of learning. From the statement above, it is known that learning by understanding and explaining again to others for several times will support the learning objective.

Learning by SEEFESR method needs some skills, namely: information sharing, asking questions, summarizing ideas of others, and paraphrasing. These skills are similar to the TPS method [15]. The demands of skills possessed by students and the phases of learning by using SEEFESR method prove that during the video recording process, the students were expected to be actively taking part in learning process. It proves that the students were actually learning. According to Manabu Sato, learning process by using lesson study is intended to give the students their learning rights, and to guarantee that the students are actually learning. Therefore, the teacher and the observer should work together to investigate on how the students learn, and how the teacher teaches through planning, implementation, and evaluation phases. These things are conducted over and over until the students are guaranteed to actually learn and their rights are delivered. Saito, E., Murase, M., Tsukui, A., \& Yeo, J. [19]. 
The learning evaluation by using SEEFESR method covered group assignment results, discussion process results, the results of assignment explanation video, and tests results. According to James A. Mc. Lounghlin \& Rena B Lewis (1994), evaluation is a systematical process in collecting data of a student, which functions to see the abilities and the difficulties encountered at that time as a material to determine what the student needs. Based on the gathered information, the teacher will be able to design realistic learning program in accordance with the objective reality. The test used was an objective test, which is a test that can be scored objectively. (Arikunto, 1995: 165). Because of the objective nature, the scoring can be conducted by using machine. The questions posed in this kind of test do not give an opportunity to give a graded score, because there are only two options to the answer, whether it is right or wrong. If the response of the students suit the desired answers then the response is right and is usually given the score of 1 . If the otherwise happens, then the response is wrong, and is usually given the score of 0 . The answer of students converges to a single, right answer. The scoring of assignments and tests used 0-100 scale. The scoring of discussion used observation outline sheet based on affective and psychomotor domains, while the scoring of video recording used right/wrong objective scale, and also based on psychomotor domains. The video recorded the students when they explained the solutions to their friends. By recording the understanding of the material through the video, the teacher was able to objectively and easily score the cognitive ability.

Learning achievement is an ability obtained through the internalization of knowledge, attitude, skill, competence, and accumulation of work experience. The learning achievement in Engineering Mechanics 4 is that the students are expected to be able to analyze structures. Its indicators are as follows: (1) students are able to analyze structures with moment-area method on beams with three-span support, (2) students are able to analyze structures with moment-area method on beams with fixed-pinned support, (3) students are able to analyze structures with moment-area method on beams with pinned-pinned support, (4) students are able to analyze structures with moment-area method on beams with fixed-pinned support, (5) students are able to analyze structure with moment-area method on beams with pinned-pinned support, (6) students are able to analyze structure with three-cycle moment method (Clapeyron) on beams with three-span support, (7) students are able to analyze structure with three-cycle moment method (Clapeyron) on beams with fixed-pinned support, and (8) students are able to analyze structure with three-cycle moment method (Clapeyron) on beams with pinned-pinned support. Thus, based on the observation and evaluation with the SEEFESR method, the learning materials were delivered in accordance with the lesson plans. However, the time allotted for the learning was not in accordance the lesson plans or it required more time for learning implementation than for planning the lessons. In addition, the learning result in the cognitive domain increased where $100 \%$ of the students passed the class as shown in Table 1. Thus, the SEEFESR method could increase the learning result.

In implementing SEEFESR, the discourse materials had been prepared in accordance with the capacity of students, covering the discourse material, the evaluation sheet, learning procedure, time, and discussion. The learning scenario was arranged with active learning atmosphere, which were grouping, understanding, discussing, finding, and others. Ausubel [2] stated that a learning can be called meaningful if information which will be learned by students is arranged in 
accordance with the cognitive structure of the students, so that they can associate new information they got with their cognitive structure. In order for meaningful learning to happen, some conditions should be met: (1) the materials that will be learned should potentially have meaning, and (2) the students learning should have an objective to perform meaningful learning so that they are ready and intent to learn meaningfully. Therefore, learning with SEEFESR method is a meaningful learning. Ausubel [2] claims that there are three benefits of meaningful learning: (a) the information learned by meaningful learning will be memorized longer than usual, (b) the information learned by meaningful learning will enable the students to learn similar material easily, (c) the information learned by meaningful learning will ease the learning of similar material, even though the material is difficult.

\section{CONCLUSION}

The result of the research shows that the learning materials were fully delivered, the students examined learned in the class to the phase of analyzing. It also shows that there was a guarantee that students were learning, and that the learning evaluation could be conducted objectively. Thus, the learning objective was achieved based on the basic competences, and the learning process itself left a good impression on students.

\section{REFERENCES}

[1] Allwright, D., \& Bailey, K. M. (1991). Focus on the language classroom: An introduction to classroom research for language teachers. Cambridge University Press.

[2] Ausubel, D. P. (1968). The Psychology of Meaningful Learning; an Introduction to School Learning. Grune and Stratton.

[3] McLoughlin, J. A., \& Lewis, R. B. (1994). Assessing special students. Macmillan College.

[4] Bamiro, A.O. (2015) Effects of guided discovery and think-pair-share strategies on secondary school students' achievement in chemistry. Sage open, Volume 1.

[5] Brown, B.W and Daniel H. (1980) Theory and Measurement.

[6] Conklin, J. (2005). A Taxonomy for Learning, Teaching, and Assessing: A Revision of Bloom's Taxonomy of Educational Objectives Complete Edition.

[7] Fitzgerald, D. (2013). Employing think-pair-share in associate degree nursing curriculum. Teaching and Learning in Nursing, 8(3), 88-90.

[8] Hassumani, D., Cancellieri, S., Boudakov, I., Upadhya, S., \& Sobering, A. K. (2015). Quiz Discuss Compare: Using Audience Response Devices to Actively Engage Students. Medical Science Educator, 25(3), 299-302.

[9] Husna, M. Ikhsan, S. F. (2013). Improvement of ability in Solving Problems and Communication Junior high school students in the field of Mathematical Through Cooperative Learning Think Pair Share. Peluang, 1(April), 81-92

[10] Joyce, B. R., Weil, M., \& Calhoun, E. (1986). Models of teaching (Vol. 499). Englewood Cliffs, NJ: Prentice-Hall.

[11] Kaddoura, M. (2013). Think pair share: A teaching learning strategy to enhance students' critical thinking. Educational Research Quarterly, 36(4), 3.

[12] Lyman, F. (1987). Think-pair-share: An expanding teaching technique. Maa-Cie Cooperative News, 1(1), 1-2.

[13] Lyman, F., \& Davidson, N. E. I. L. (2004). Cooperative learning in preservice teacher education at the University of Maryland. SUNY series, Teacher Preparation and Development, 83.

[14] McLoughlin, J. A., \& Lewis, R. B. (1994). Assessing special students. Macmillan College.

[15] McTighe, J., \& Lyman, F. T. (1988). Cueing thinking in the classroom: The promise of theoryembedded tools. Educational Leadership, 45(7), 18-24. 
[16] Murthy, S., Warriem, J. M., \& Iyer, S. (2017). Technology Integration for Student-Centered Learning: A Model for Teacher Professional Development Programs. In Emerging Practices in Scholarship of Learning and Teaching in a Digital Era (pp. 55-74). Springer Singapore.

[17] Permadi Marhaeni, I. M., Putra, A., \& Nyoman Adi Jaya, I. (2013). the Effect of Think Pair Share Teaching Strategy To Students' Self-Confidence and Speaking Competency of the Second Grade Students of Smpn 6 Singaraja, 1. eJournal Master Programe, Pendidikan Ghanesa University, Vol.1.

[18] Rudiyanto, O. S., \& Sigit, D. (2013). Influence of Learning Think Pair Share (TPS) To Activities Learning and Student Achievement Class X SMAN 6 Malang in academic year 2012/2013 to Content Redox Reactions.

[19] Saito, E., Murase, M., Tsukui, A., \& Yeo, J. (2014). Lesson Study for Learning Community: A guide to sustainable school reform. Routledge.

[20] Schunk, D. H. (1996). Learning theories. Printice Hall Inc., New Jersey, 1-576.

[21] Sugiarto, D., \& Sumarsono, P. (2014). The Implementation of Think-Pair-Share Model to Improve Students' Ability in Reading Narrative Texts. International Journal of English and Education, 3(3), 206-215.

[22] Suharsimi, A. (2009). Dasar-dasar Evaluasi pendidikan. Jakarta: Bumi Aksara.

[23] Sumarni, S. (2016, November). Think Pair Share Effect of Understanding the Concept and Achievement. In Proceeding of the International Conference on Teacher Training and Education (Vol. 2, No. 1, pp. 783-787).

[24] Surayya, L., Subagia, I. W., \& Tika, I. N. (2014). Influence of Learning Think Pair Share To IPA Learning Outcomes Viewed From Critical Thinking Skills Students, eJournal Master Programe, Pendidikan Ghanesa University, Vol. 4.

[25] Widiyaningsih. A. (2012). Effectiveness of Mathematics Learning Approach Using InductiveDeductive collaborated with Think Pair Share To Concept Training, Sunan Kalijaga University Yogyakarta. 